\title{
SYMPOSIUM ON THE BRICS APPROACH TO THE INVESTMENT TREATY SYSTEM
}

\author{
CHINA'S INNOVATIVE ISDS MECHANISMS AND THEIR IMPLICATIONS
}

Huiping Chen*

International arbitration before Western-based institutions is the dominant mode of investor-state dispute settlement (ISDS). The Washington-based International Centre for Settlement of Investment Disputes (ICSID), the Hague-based Permanent Court of Arbitration, the Arbitration Institute of the Stockholm Chamber of Commerce, and the International Court of Arbitration of the Paris-based International Chamber of Commerce handle the vast majority of the world's international investment disputes. ICSID alone administers over sixty percent of the cases, while the others account for an additional twenty percent. ${ }^{1}$ Yet China has begun to innovate in ISDS over the last few years. These innovations have taken three main forms. The first is the extension of the jurisdiction of existing commercial arbitral institutions in China to cover foreign investment disputes. The second is the creation of new Chinese courts to possibly handle contractual investment disputes. The third is the formation of joint arbitration centers with states in regions where China invests heavily, such as Africa. This essay describes these changes and argues that they should be understood as reflecting an important facet of China's broader international strategy. In particular, the recent innovations aim to furnish adequate protection to Chinese investors in foreign countries, particularly developing states; actively shape international discourses on international investment law; and offer alternative, Chinese-initiated institutions that will break the monopoly of the West.

\section{China's Innovative Approach to ISDS}

Since 2015, China has begun to offer a broader range of ISDS services. These reforms could result in significant changes to the current global system.

First, China is expanding the jurisdiction of its existing arbitral institutions to encompass foreign investment disputes. There are many arbitral institutions in the country, but they have traditionally handled domestic and international commercial disputes involving Chinese businesses, rather than foreign investment disputes.

The Shenzhen Court of International Arbitration (SCIA) and the China International Economic Trade Arbitration Commission (CIETAC) illustrate the new approach. In 2016, the SCIA updated its arbitration rules to handle foreign investment disputes, and thus became the first Chinese arbitral institution unquestionably to take on investor-state claims. ${ }^{2}$ The SCIA also formulated guidelines to enable the administration of investment

* Xiamen University School of Law, China. I would like to thank Prof. Anthea Roberts and Prof. Congyan Cai for comments on earlier drafts.

${ }^{1}$ According to the UN Conference on Trade and Development, there were 855 cases as of December 31, 2017. ICSID administered 542 of these cases while other arbitration institutions handled another 188. The rest were not administered by any institution or are cases on which data is unavailable. Arbitral Rules and Administering Institution, UNCTAD InveSTMENT Policy Hub (Dec. 31, 2017).

2 The SCIA 2016 Arbitration Rules provide that the SCIA “accepts arbitration cases related to investment disputes between states and nationals of other states.” Shenzhen Court of Int'l Arbitration, 2016 Arbitration Rules art. 2(2) (effective Dec. 1, 2016).

\footnotetext{
The American Society of International Law and Huiping Chen (C) 2018. This is an Open Access article, distributed under the terms of the Creative Commons Attribution licence (http://creativecommons.org/licenses/by/4.0/), which permits unrestricted re-use, distribution, and reproduction in any medium, provided the original work is properly cited.
} 
cases under the Arbitration Rules of the UN Commission on International Trade Law (UNCITRAL). ${ }^{3}$ Moreover, in late 2017, the Shenzhen municipal government merged the Shenzhen Arbitration Commission into the SCIA to make the court stronger and more competitive. ${ }^{4}$ This action shows that the expansion of the SCIA's jurisdiction to include ISDS enjoys the central government's approval and support. SCIA is now working to build its capacity to attract investment disputes and entered into a Cooperation Agreement with ICSID in June 2018. ${ }^{5}$

The reforms of CIETAC— the oldest and largest arbitral institution in China—are no less significant. In 2017, CIETAC for the first time adopted and implemented Arbitration Rules for International Investment Disputes. ${ }^{6}$ The Rules clearly provide that CIETAC can accept cases involving international investment disputes arising out of contracts, treaties, laws, and regulations, or other instruments between an investor and a state. Although CIETAC is not a governmental organization, the expansion of its jurisdiction is likely to win the government's approval. These developments signal that the Chinese government pays special attention to, and intends to participate in, the resolution of investor-state claims.

Second, China is establishing new courts to hear international commercial cases. The Supreme People's Court (SPC) officially set up its First International Commercial Court in Shenzhen and Second International Commercial Court in Xi'an in late June 2018, ${ }^{7}$ both under the supervision and coordinating authority of the SPC's Fourth Civil Division. ${ }^{8}$ Plans pertaining to their jurisdiction have evolved somewhat in recent months: The original idea was to have the new courts focus exclusively on disputes arising from the Belt and Road Initiative (BRI), ${ }^{9}$ which is the Chinese government's initiative to construct a Sino-centric network of economic activity through infrastructure investment, trade, and cultural exchanges with a collection of states in Asia and Africa. It now appears, however, that the courts will be able to hear other kinds of cases as well. ${ }^{10}$ At a press conference on June 28, 2018, an SPC official explained that the courts will accept a range of international commercial disputes between equal commercial entities. ${ }^{11}$ This jurisdiction will exclude investor-state disputes arising from treaties, but might still permit jurisdiction over cases arising out of contracts between investors and a host government.

The new courts are distinct from a traditional court of justice or commercial court of arbitration and mediation in that they aim to create a one-stop center for dispute resolution, linking litigation, arbitration, and mediation. To

\footnotetext{
${ }^{3}$ Shenzhen Court of Int'l Arbitration, Guidelines for the Administration of Arbitration under the UNCITRAL Arbitration Rules (effective Dec. 1, 2016).

${ }^{4}$ SCLA and SAC Arbitration Institutions Merge to Form New Arbitration Centre in Shenz̧en, Herbert Smith FreehilLs, Arb. Notes (Feb. 14, 2018).

${ }^{5}$ Shenzhen Court of Int'l Arbitration, SCIA Concludes Cooperation Agreement with ICSID in Washington, D.C. (June 27, 2018).

${ }^{6}$ China Council for the Promotion of Int'l Trade (China Chamber of Int'l Commerce), China International Economic and Trade Arbitration Commission International Investment Arbitration Rules (For Trial Implementation) (effective October 1, 2017).

${ }^{7}$ China Int'l Commercial Court, The First International Commercial Court and the Second International Commercial Court of the Supreme People's Court Started to Operate Officially (June 29, 2018).

${ }^{8}$ China Int'l Commercial Court, Opinion Concerning the Establishment of the Belt and Road International Commercial Dispute Resolution Mechanism and Institutions (June 27, 2018).

${ }^{9}$ This much is apparent from the title of the most important document in the creation of the international commercial courts. See id.. The opinion was reviewed and passed by the Central Leading Group for Comprehensively Deepening Reform on January 23, 2018, and officially issued by the General Office of the Communist Party Central Committee and the General Office of the State Council of the People's Republic of China on June 28, 2018. Id.

${ }^{10}$ China Int'l Commercial Court, Provisions of the Supreme People's Court on Several Issues Regarding the Establishment of the International Commercial Court (June 27, 2018).

${ }^{11}$ See China Int'l Commercial Court, The State Council Information Office Held a Press Conference on the "Opinion on the Establishment of “The Belt and Road' International Commercial Dispute Settlement Mechanism and Institutions” (June 28, 2018).
} 
realize this goal, the courts will set up an International Commercial Expert Committee and select major international commercial mediation and arbitration institutions to work with them. ${ }^{12}$ The idea of international commercial courts derives from the many commercial courts that exist in other states. The more specific idea of combining multiple functions in one court draws inspiration from the Singapore International Commercial Court, ${ }^{13}$ the Singapore International Arbitration Centre, ${ }^{14}$ and the Singapore International Mediation Centre, ${ }^{15}$ which operate in tandem to provide a complete suite of options for the resolution of cross-border disputes.

Third, China is building joint arbitration centers to resolve investor-state and commercial disputes with other regions, especially those in which China is investing heavily. For example, the China Law Society proposed the idea for a China-Africa Joint Arbitration Center (CAJAC) in 2015, which the Chinese government and fifty African countries adopted at the Johannesburg Summit and the Sixth Ministerial Conference of the Forum on ChinaAfrica Cooperation. ${ }^{16}$ Thus far, CAJAC has set up five centers: three in China (Shanghai, Beijing, and Shenzhen) and two in Africa (Johannesburg and Nairobi). In these locations, CAJAC will provide arbitration, mediation, and conciliation services ${ }^{17}$ that bypass the jurisdiction of local courts, local arbitration institutions, and other international arbitration institutions. ${ }^{18}$

Together the new ISDS reforms offer a number of new options to Chinese investors. They were created primarily for the BRI, but are not limited to disputes arising from investments in that domain.

\section{How This Approach Serves China's Strategy on International Engagement}

The new mechanisms for investor-state dispute settlement should be understood as serving China's interests in three ways.

First, the mechanisms answer China's pressing need to protect Chinese investments abroad, particularly in developing states. The BRI has aimed to strengthen international cooperation and promote Chinese outbound investment in the states in the Belt and Road domain. As a result, from 2014 to 2016, Chinese investment in those states surged to US $\$ 48$ billion $^{19}$ and is expected to continue to increase.

The huge volume of this investment is a source of special concern to the Chinese government. As the BRI advances, the number of investor-state disputes between Chinese investors and host governments could very well increase. But most of the countries in the BRI domain are developing or least developed countries whose domestic laws on foreign investment are inadequate. In addition, the other dispute settlement mechanisms that are currently available to Chinese investors are quite limited: some of the international investment agreements (IIAs) that China concluded with the BRI countries have not entered into force, or do not include a dispute settlement provision, or provide for investor-state settlement only for disputes over the amount of an expropriation. And in the near future, China is unlikely to be able to update its IIAs to allow for broader and stronger ISDS

${ }^{12}$ China Int'l Commercial Court, supra note 10.

13 Singapore International Commercial Court.

14 Singapore International Arbitration Centre.

15 Singapore International Mediation Centre.

${ }^{16}$ China-Africa Joint Arbitration Centre Shanghai; The Forum on China-Africa Cooperation Johannesburg Action Plan (20162018), Ministry of Foreign Affairs of the People’s Republic of China (Oct. 12, 2015).

${ }^{17}$ The China Africa Joint Arbitration Centre, Dentons (Jan. 26, 2017).

${ }^{18}$ For example, the Arbitration Foundation of Southern Africa International clearly states on its website that its jurisdiction does not cover China-Africa disputes. See AFSA InTERnational.

${ }^{19}$ China Ministry of Commerce, Report on Development of China's Outward Investment and Economic Cooperation 124 (2016) (Chin.). 
options for Chinese investors. In these conditions, Chinese foreign investors could face substantial and even excessive risk.

The new ISDS mechanisms could help to mitigate this problem. Take CAJAC as an example. Since the beginning of the twenty-first century, China has invested extensively in African countries. In 2016 alone, Chinese total investment in Africa reached US $\$ 2.4$ billion. ${ }^{20}$ But African municipal laws and judicial systems have proven inefficient, uncertain, and highly restrictive on matters involving foreign parties. ${ }^{21}$ China has concluded thirty-four BITs with African countries, but the standard of protection is low and international arbitration available for investor-state claims is very limited. ${ }^{22}$ Moreover, some countries, like South Africa, have adopted policies that generally permit the resolution of foreign investment disputes only in their domestic courts. CAJAC helps to resolve these difficulties by offering a mutually agreeable forum as an alternative.

Second, the new mechanisms enable China to amplify its voice in the international discourse on international investment agreements. Mostly because of the BRI, China has become the second largest economy in both capital importing and exporting and is already a net capital-exporting state. ${ }^{23}$ Consequently, since 2014 China has sought to "[v]igorously participate in the formulation of international norms, ... strengthen [its] discourse power and influence in international legal affairs, [and] use legal methods to safeguard [its] sovereignty, security, and development interests." 24

With this ambition in mind, China enjoyed some success in pursuing the adoption of the G20 Guiding Principles for Global Investment Policymaking in 2016, ${ }^{25}$ the proposal to include the issue of investment facilitation on the World Trade Organization's agenda in 2017, ${ }^{26}$ and the conclusion of the Outlines for BRICS Investment Facilitation in 2017. ${ }^{27}$ China has also been involved in the ongoing global reform of investor-state dispute settlement; when UNCITRAL proposes reform options, China actively participates in the negotiations. But China's influence in the multilateral setting does not yet match its economic status.

In this context, the new ISDS mechanisms benefit China in a couple of ways. For one, they operate as trial runs for potential global reforms of the future. Once the mechanisms prove successful, China could incorporate institutions such as the SCIA and CIETAC in future IIAs as options for traditional investor-state dispute settlement, or propose its international commercial courts as an alternative to traditional ISDS. In addition, as China pursues innovative models for ISDS, such as "arbitration + mediation," it will accumulate experience and human resources, both of which will empower China to offer new perspectives on reforming the ISDS system.

Third and finally, China's reforms help to break the monopoly of existing Western-initiated institutions. Although the SCIA and CIETAC expanded their jurisdiction just recently, they will conceivably play a significant role in the resolution of future investment disputes. For IIAs to which China is a party, Chinese investors may refer their treaty-based claims to the SCIA or CIETAC for resolution if the UNCITRAL rules are applicable or ad hoc arbitration is available. Contractual claims could also be referred to these institutions for resolution. For infrastructure investments that require a concession agreement between the host state and Chinese investors, the latter may

${ }^{20}$ China Ministry of Commerce, 2016 Statistical Bulletin of China's Outward Foreign Direct Investment 47 (2016) (Chin.).

${ }^{21}$ Francis Kariuki, The Vision of Co-Building China-Africa Joint Arbitration Centres in Different Legal Systems.

${ }^{22}$ Huiping Chen, Sino-African BITs Practice: A New Legal Paradigm?, Soochow L.J. 65 (No. 2, 2012).

${ }^{23}$ UNCTAD, World InVESTMENT Report 2017, at 14 (2018).

${ }^{24}$ CCP Central Committee Decision Concerning Some Major Questions in Comprehensively Moving Governing the Country According to the Law Forward, China Copyright \& Media Blog (Oct. 30, 2014).

${ }^{25}$ G20 Guiding Principles for Global Investment Policymaking, G20 Trade Ministers Meeting Statement, Shanghai, Ann. III (July 9-10, 2016).

${ }^{26}$ World Trade Org., Joint Ministerial Statement on Investment Facilitation for Development, WTO Doc. WT/MIN(17)/59 (2017).

${ }^{27}$ BRICS, Outlines for BRICS Investment Facilitation (Aug. 31, 2017). 
insist that any dispute arising under the agreement be referred to Chinese arbitral institutions. Similarly, China could establish the jurisdiction of China's international commercial courts through bilateral memorandums of understanding with some seventy individual nations along the Belt and Road routes. Together these changes would shift the locus of China-related dispute resolution from ICSID or other Western institutions to China, where Chinese parties will encounter a system that is more familiar to them.

Other states are helping to facilitate this shift. The creation of CAJAC, for example, reflects not only Chinese interests, as discussed above, but also the desire of African countries, many of which are dissatisfied with the established international tribunals whose rulings have mostly gone against them. ${ }^{28}$ In this sense, the new mechanisms reflect a win-win strategy against the hegemony of the West.

Ultimately, the new institutions may compete with and exist alongside ICSID and the other established arbitral tribunals, just as the Asian Infrastructure Investment Bank and the BRICS New Development Bank operate alongside the International Monetary Fund and the World Bank. And they will have certain advantages in this competition. For instance, whereas investor-state dispute settlement before established international institutions typically entails high costs and lengthy delays, the SCIA in 2016 used the "arbitration + mediation" model to successfully handle an investment case between two equal parties from the United States and China within only thirteen days and at a much lower cost. ${ }^{29}$ Over time, such efficiency is likely to attract more and more investors from both China and other countries. The "arbitration + mediation" model is also likely to prove attractive to investors, as it is more flexible and efficient than traditional arbitration.

\section{Conclusion}

China has created innovative mechanisms to deal with investor-state claims stemming from its BRI, but the significance of these mechanisms extends well beyond the BRI. The aim is not to replace one hegemony with another but to create alternatives that protect Chinese investors, amplify China's voice, and break the existing monopoly of the West. In the long run, these new reforms could very well succeed.

\footnotetext{
${ }^{28}$ See Kariuki, supra note 21.

${ }^{29}$ Shenzhen Court of Int'l Arbitration, The Latest Development of the Arbitration Innovation in the Special Zone Reported by Shenzhen Special Zone Daily and Legal Daily (Jan. 19, 2018) (Chin.).
} 